\title{
Causes of Default on Micro - Credit among Women Micro - Entrepreneurs in Kenya. A Case Study of Women Enterprise Development Fund (Wedf) Msambweni Constituency
}

\author{
Rashid Mwatemo Kamanza \\ Submitted to the Department Of Commerce and Economics in the School for Human Resource Development of \\ JomoKenyatta University of Agriculture and Technology (Jkuat) Kenya
}

TABLE OF CONTENTS

Page

Title page

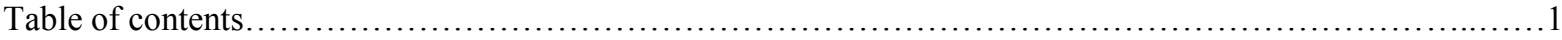

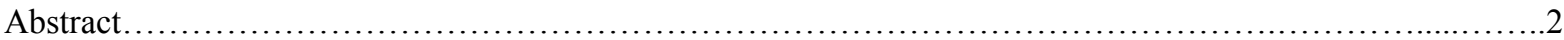

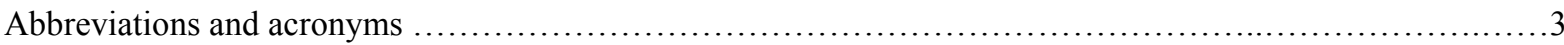

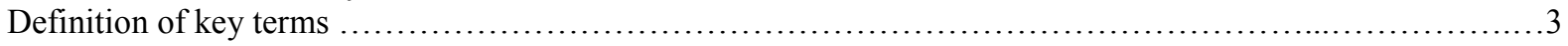

\section{INTRODUCTION}

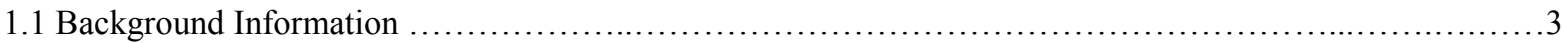

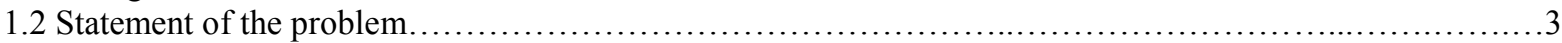

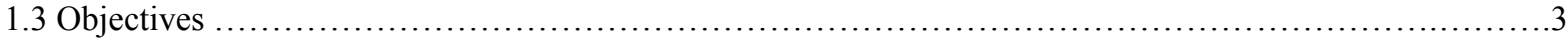

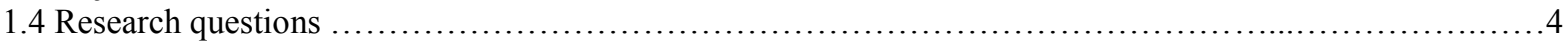

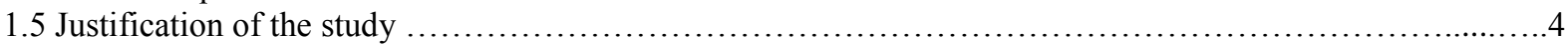

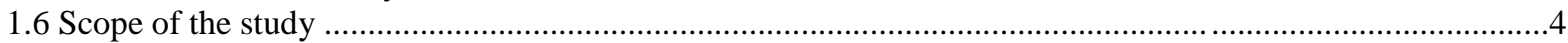

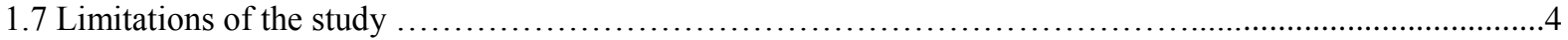

\section{LITERATURE REVIEW}

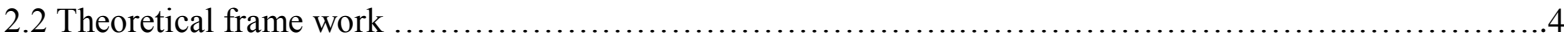

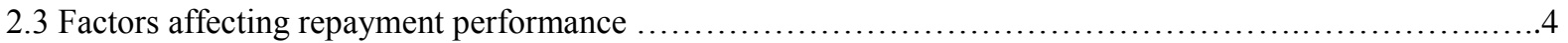

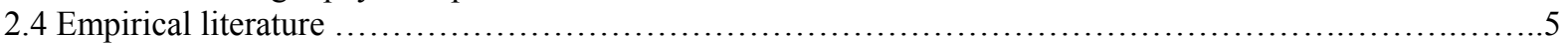

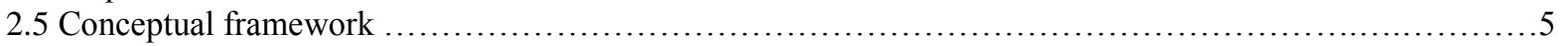

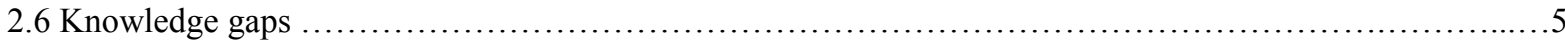

III. RESERCH METHODOLOGY

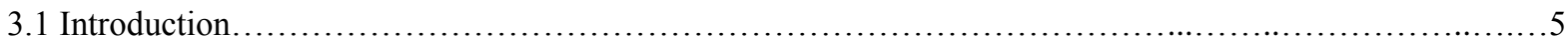

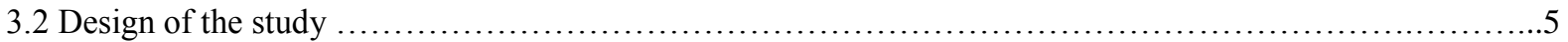

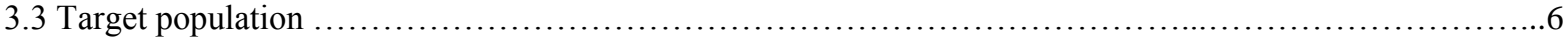

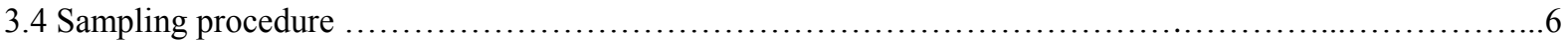

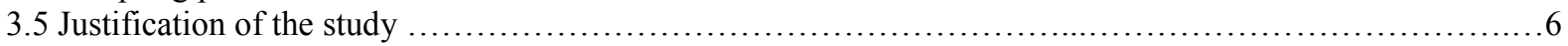

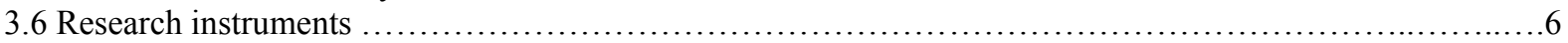

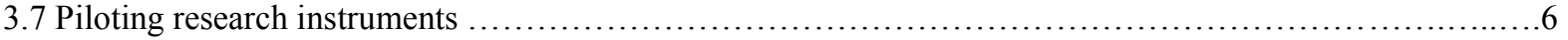

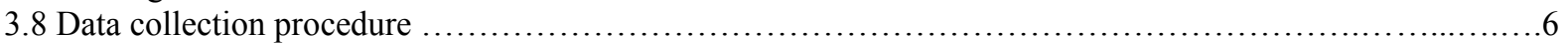

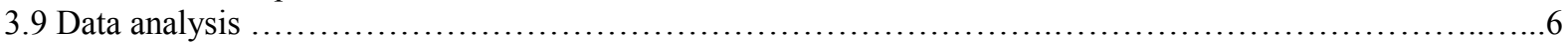

\section{DATA ANALYSIS, PRESENTATION AND FINDINGS}

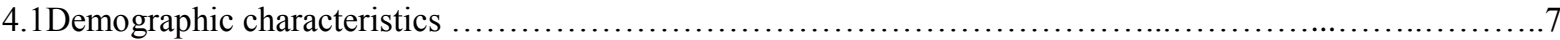

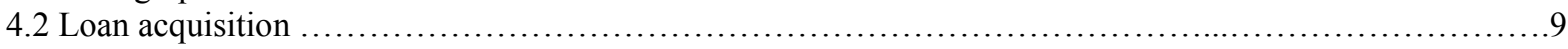

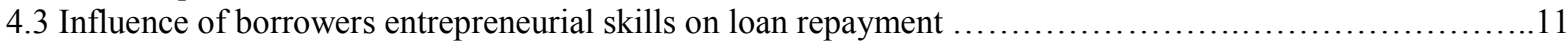

4.4 How diversion of loan funds by borrowers influences loan repayment......................................

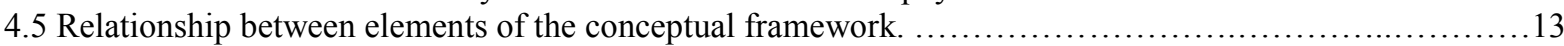

V. CONCLUSION AND RECOMMENDATION

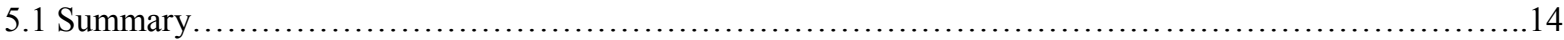

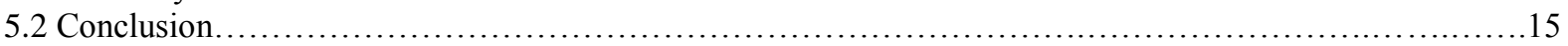

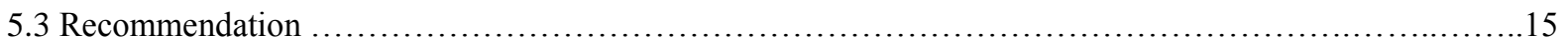

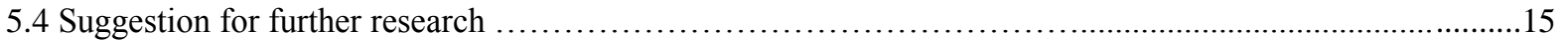




\title{
LIST OF TABLES
}

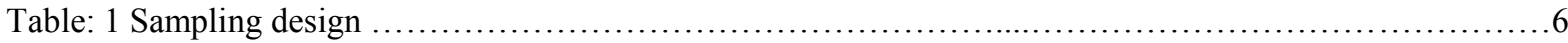

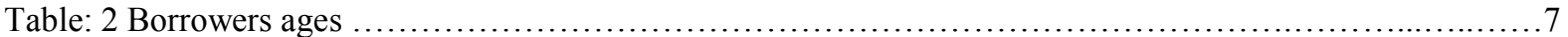

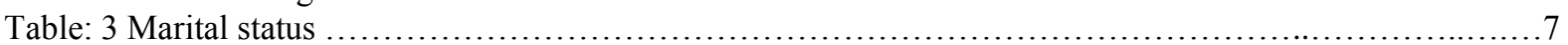

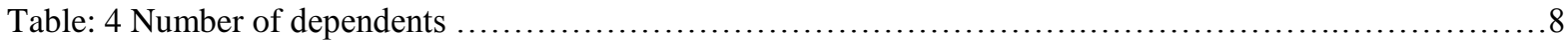

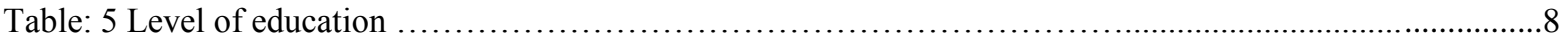

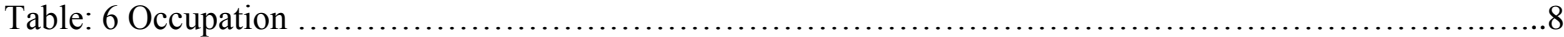

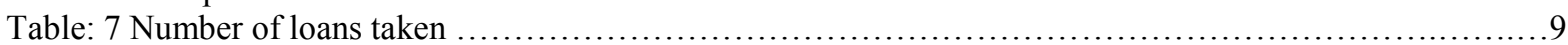

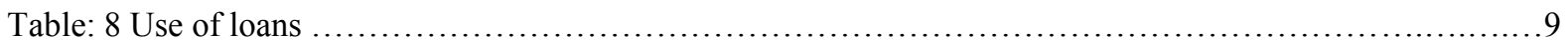

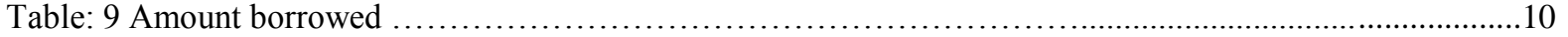

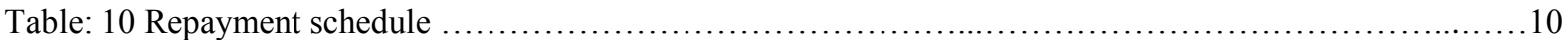

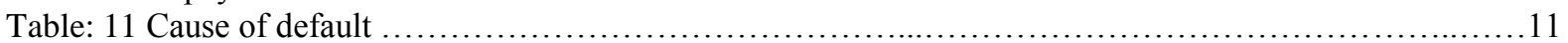

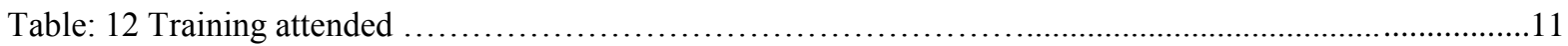

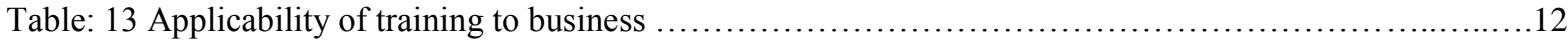

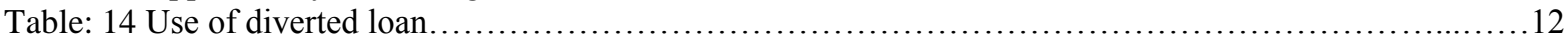

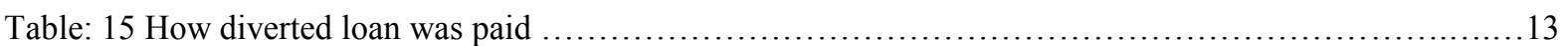

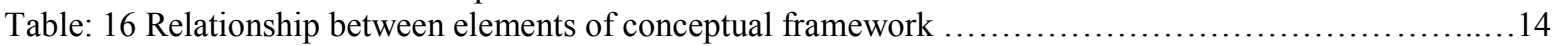

\section{LIST OF FIGURES}

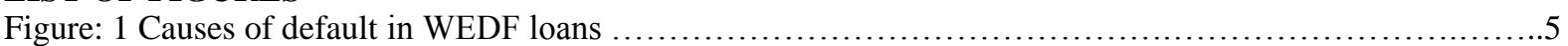

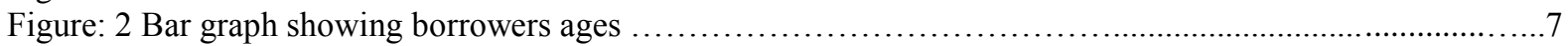

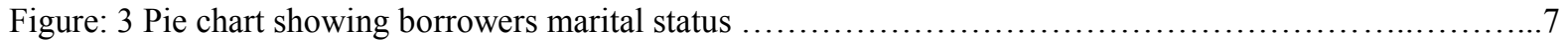

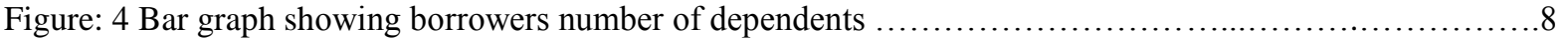

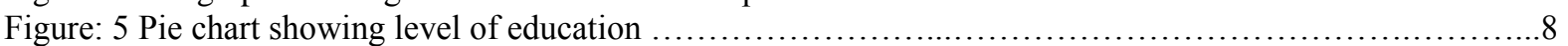

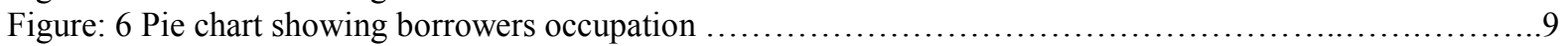

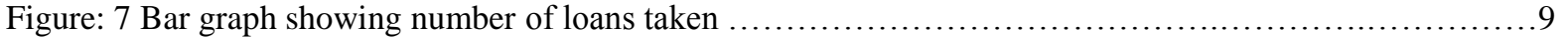

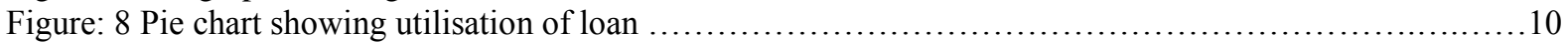

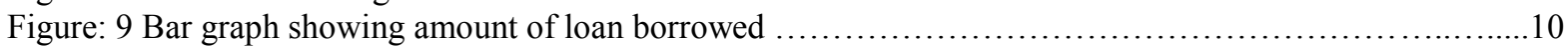

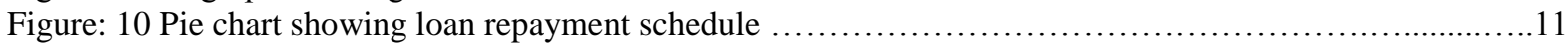

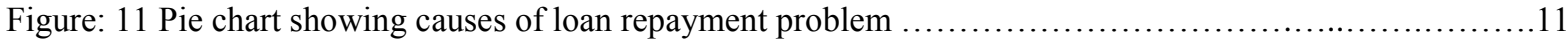

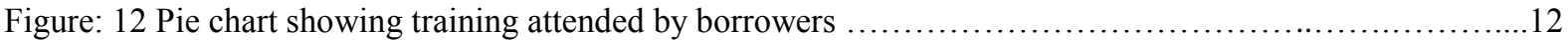

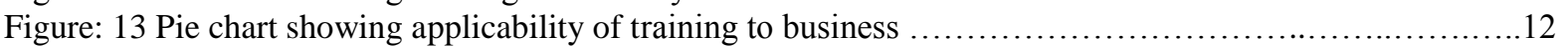

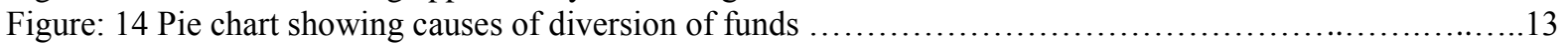

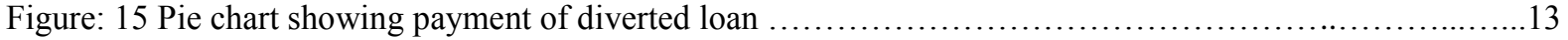

\begin{abstract}
The government of Kenya has developed many credit schemes aimed at providing cheap credit to women and the disadvantaged groups in the society however many of these programs have sustained heavy losses due to poor loan repayment. The main objective of this research was to establish the causes of default in micro-credit advanced to small scale women entrepreneurs by WEDF within Msambweni Constituency in Kenya. The specific objectives to be investigated were how business failure influences loan repayment, the influence of gender roles on loan repayment, the influence of borrower's entrepreneurial skills on loan repayment and how diversion of loan funds by borrowers affected the repayment of such loans. The study targeted a total of 74 women groups operating in the constituency which had benefited from the facility. Out of the 74groups, 19 groups were sampled each with membership of 10members, out which 4 members were picked from each of 19 groups using a simple random sampling for each stratum, so that every member of the sample population could have an equal and independent chance of being selected as a respondent. Data was collected by use of structured and semi-structured questionnaire and analysed by using quantitative technique and tabulated frequency tables, pie charts and bar graphs. The study found out that the amount of money given by WEDF was inadequate for investment that would generate returns to repay the loan and sustain the business and the entrepreneur, multiple and competing gender roles robbed off majority of the women entrepreneurs their time to attend to businesses; many did not find the applicability of the training attended in the running of their business and diversion of loans was true and it lead to repayment problems as the funds were used for other critical purposes but un intended. The recommendations are, the amount of loan advanced to women entrepreneurs be increased so that they can have adequate capital, loan beneficiaries be trained and advised to have other income generating activities so as to avert diversion of loan funds for other purpose.
\end{abstract}




\author{
Abbreviations and Acronyms \\ MFIs - Micro Finance Institutions, MDGs- Millennium Development Goals, SMEs - Small and \\ Medium Enterprises, WEDF -Women Enterprise Development Fund.
}

\title{
Definition of Key Terms
}

The following will be the operational definitions of key terms used in this study.

Defaulting: Failure to pay money that one owes at the right time, Capital: Money or property especially when used to start a business or produce more wealth, Collateral: Property or other goods that one promises to give someone if he/she unable to pay back the money lent, Creditworthy: People considered being able to pay debts, Entrepreneurs: Someone who starts a business or arranges business deals in order to make money often in a way that involves financial risks, Financial services: Provision of loans and savings by financial institutions such as banks, Loan: An amount of money borrowed from a bank or financial institution, Micro-credit: Small loans given to the poor and underprivileged population for income generating activity that will improve their standard of living, Microfinance: Is the provision of financial services to the poor and low income clients who traditionally lack access to banking and related activities.

\subsection{Background information}

\section{Introduction}

Over the past years women have experienced many obstacles in accessing credit from conventional financial institutions in Kenya. Because of the credit constrain, a number of microfinance institutions have emerged to provide credit predominantly to women. Burjorjee et al (2002), FINCA (2007) argues that most women are poorer than men on average and lack collateral, thus are more credit-constrained. Muhammad Yunus (2004) noted that women have greater long-term vision and have the capacity to bring changes in their lives step by step. He further noted that women are excellent managers of scarce resources and utilise every resource to the maximum. The major problem that majority of women have experienced in Kenya is investing the loan funds acquired in projects the will that will generate profit to enable them repay the loans so as to build a good credit history that will enable them qualify for more loans in future. Credit default has been a major challenge to many women borrowers in Msambweni Constituency in Kenya, for a long time this has made some women borrow from relatives, friends and family members so as to repay their loans, especially when their investments turn out to be unprofitable to support the repayment of the loan or when the funds are diverted to other unintended but critical needs which makes them trapped in a double debt spiral. The study focused on Women Enterprise Development Fund (WEDF) operations in Msambweni Constituency. The Fund was established by the government of Kenya to provide an alternative financial service to women who are excluded from the formal and informal financial sectors. The Fund provides accessible and affordable credit to support women start and or expand business for wealth and employment creation.

\subsection{Statement of the problem}

Majority of the Kenyan women are poor, various approaches to empower them economically have been developed by the Kenyan government to alleviate them from absolute poverty since independence, however this objective has not yet been fully realised. The government came up with various credit schemes in view of empowering women and the underprivileged, schemes such as the Youth Enterprise Fund, Women Enterprise Fund and recently the uwezo fund was launched to bridge the gap between women and the youth who been deprived of credit. A survey conducted in 2006 on well-being in Kenya revealed that $50.8 \%$ of women are poor and cannot access credit from conventional financial institution such as banks as they lack collateral. Gibbons, (1992) argues that the best way of addressing the problem of poverty is to let the poor people engage themselves in income generating activity. The Fund is intended to provide accessible and affordable credit to support women start and / or expand business for wealth and employment creation. It also aims at enabling the government realize the 3rd Millennium Development Goal (MDG) on "gender equality and empowerment of women" and play a catalytic role attaining the social pillar in the Vision 2030.

\subsection{Objectives}

\subsubsection{General objective}

The study was to establish the causes of default on micro-credit among women micro-entrepreneurs within Msambweni Constituency. In view of this, the researcher investigated the causes of default in WEDF loans.

\subsubsection{Specific objectives of the study.}

The specific objectives of the study were;

i. To investigate how business failure influences the loan repayment. 
ii. To find out the influence of gender roles on loan repayment.

iii. To establish the influence of borrower's entrepreneurial skills on loan repayment.

iv. To establish how diversion of loan funds by borrowers influences loan repayment.

\subsection{Research questions.}

i. How does business failure affect the loan repayment?

ii. How do gender roles influence the repayment?

iii. How do entrepreneurial skills influence the loan repayment?

iv. How does diversion of funds influence the loan repayment?

\subsection{Justification of the study}

The study was founded on the rationale that there has been a high rate of default in the loans advanced by WEDF and default has many undesirable and unintended effects; the financier will be unable to revolve the funds and the defaulter will also not qualify for more loans. The findings will assist the borrower to invest wisely and proper management of funds hence avoid default and enable her qualify for more credit. The WEDF will also continue providing cheap loans to other deserving women as well as remain in business as it will have higher cash flow hence the country's objective of reducing poverty and empowering women achieved.

\subsection{Scope of the study}

The study mainly focused on the Women Enterprise Development Fund focusing on women groups that had obtained loans from WEDF in Msambweni Constituency.

\subsection{Limitations}

i. Difficult in accessing required information as members were reluctant to reveal their financial matters.

ii. The study was also affect by money constraints as the research was funded by the researcher.

iii. There was very little secondary data about the Constituency Women Enterprise Fund; most of the information is obtained from the internet.

\subsection{Introduction}

\section{Literature Review}

Literature review covered relevant literature with the aim of gaining insight into the factors that cause micro-credit default in WEDF loans within Msambweni Constituency. It covers; theoretical framework, empirical literature and conceptual frame work which shed light on causes of loan default.

\subsection{Theoretical Frame work}

\subsubsection{Solidarity circle theory.}

The study adopted the solidarity circle theory advanced by Muhammad Yunus, a successful pioneer of micro-credit of the Grameen Bank in the 1970's in Bangladesh. Mohammed Yunus addressed the problem faced by the poor from accessing credit. He designed a credit programme that did not require any collateral as opposed to the conventional financial institutions. He applied group lending (joint liability) methodology in micro-credit to minimize the level of loan delinquency by the borrowers where the members of a group guaranteed each other and when a member defaults the whole group is denied future credit so in order for members to continue enjoying credit they closely monitored each other activities in order to avoid default. This theory is relevant to this study in that the loan repayment by the borrower is dependent on various aspects such business performance of the borrower, the borrower's entrepreneurial skills and diversion of the loan funds by the borrowers.

\subsection{Factors Affecting Repayment Performance}

Studies on factors influencing loan repayment are very sparse and limited mainly to microfinance experience in the low and middle income countries (Derban et al., 2005; Silwalq, 2003). The results of the studies show mixed result based on past literature. Factors influencing loan repayment is divided into four factors; individual / borrowers factors such as entrepreneurial skills, firm factors such as close monitoring of payments, loan factors such inadequacy and the institution / lender factors such as high interest charged.

2.3.1. Firm Characteristics that influence Loan Repayment. Several studies link the repayment performance with firm characteristics. Nannyonga (2000), Arene (1992) and Oke et al. (2007) Oke et al. (2007) noted that business's profits significantly influenced loan repayment.

2.3.2. Individual / Borrower Characteristics Influencing loan Repayment. Godquin (2004) suggested training, basic literacy and health services had a strong positive impact on repayment performance. Roslan and Mohd 
Zaini (2009) found that borrowers that did not have any form of training in relation to their business had a higher rate of default than their counter part who had trained in entrepreneurship.

2.3.3. Loan characteristics affecting Loan repayment performance: Roslan et al.(2009), Mohd (2009); Njoku (1997) and Ugbomeh et al.,( 2008) found that loan characteristics play an significant role in determining repayment performance. Copisarow (2000) also noted that defaults may arise from poor program design and implementation, but not from problems with the borrowers.

2.3.4. Institutional / lender characteristics influencing repayment: Vigenina and Kritikos (2004) found that individual lending has three elements namely the demand for non-conventional collateral, a screening procedure which combines new with traditional elements and dynamic incentives in combination with the termination threat in case of default, which ensure high repayment rates up to 100 percent.

\subsection{Empirical Literature}

Several studies that have been conducted in many developing countries concerning micro-credit repayment. Vigano (1993) in his study on of development bank of Burkina Faso, established that being women, married, aged, more business experience, value of assets, timeliness of loan release, small periodical repayments, project diversification and being a pre-existing depositor has a strong and positively relationship to the loan repayment performance. Kashuliza (1993) also analysed the determinants of loan repayment in smallholder agriculture in Tanzania and found out that level of education, attitude towards repayment; business's income and off-farm income positively had an influence on loan repayment with farm income being significant, while age, household expenditure and household size having a negative influence on loan repayment performance with household expenditure being significant. Njoku and Odii (1991) studied determinants of loan repayment under the Social Emergency Loan Scheme in Nigeria and their study showed that late release of loans, complicated loan processing procedures, loan diversion to non- agricultural enterprise, low returns from businesses resulting from low poor agricultural technologies and political considerations in loan approvals contributed to poor loan repayment performance.

\subsection{Conceptual Framework}

The researcher adopted the framework below to explain the relationship between the variables.

Independent Variables

Dependent Variable

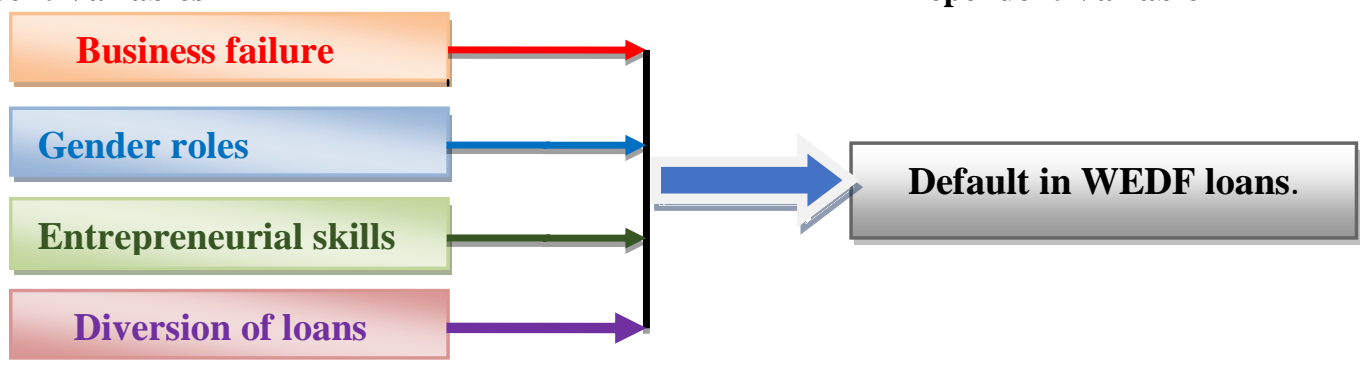

Figure 1: Causes of default in Women Enterprise Development fund loans.

Source: Researcher 2013

\subsection{Knowledge gaps}

There have been attempts in the past to study Micro financing and Micro lending but much focus has been on the impact of MFIs in poverty alleviation and job creation in Kenya. Very little has been done to find out causes of loan default in funds provided by the government such as the WEDF in Msambweni Constituency, therefore this research was intended to address the gap.

\subsection{Introduction}

\section{Research Methodology}

This chapter presents the methodology and research design that was used to implement the study.

\subsection{Design of the study}

Descriptive survey design was used to assess the causes of default in repayment of loans advanced by WEDF (micro-credit) to small scale women entrepreneurs. This allowed the researcher to gather information, summarize, present, and interpret data for the purpose of clarification. Quantitative methodology was used in 
data collection and analysis, where tables, measures of central tendency (percentages), graphs, and pie charts were used to summarize the data.

\subsection{Target population}

The study targeted total population of 74 women groups operating in Msambweni constituency each with ten members and 8 loan officers (volunteers).

\subsection{Sampling procedure and sample size}

Both probability and non-probability sampling designs were employed. Sample groups under study were drawn from the 74 women groups and eight loan officers. Stratified sampling was used to select 19 groups and 2 officers which represented $25 \%$ of the total population. Out of the nineteen (19) group's four (4) members out of the 10 were sampled to constitute the sample population under study as shown by the table 1 below.

Table 1. Sampling Design

\begin{tabular}{|c|c|c|c|}
\hline Respondents & $\begin{array}{c}\text { Target population } \\
(\mathbf{1 0 0 \% )}\end{array}$ & $\begin{array}{r}\text { Sample } \\
(25 \%)\end{array}$ & $\begin{array}{c}\text { Sample } \\
\text { population }\end{array}$ \\
\hline Loan Officers & 8 & 2 & 2 \\
\hline Loan borrowers & 74 groups & 19 groups & 76 \\
\hline Total & & & 78 \\
\hline
\end{tabular}

Source: Researchers sampling 2014

\subsection{Justification of the population sample}

Sampling of 76 borrowers, four members from each of the 19 sampled groups and 2 loan officers was used in order to save on time as the population was spread over the entire constituency which is vast and it was expensive to carry out census in terms of time and finances so to save on cost a sample was used.

\subsection{Research instruments}

Two sets of questionnaires were developed and used for data collection. The use of quantitative method was relatively cheap and time saving since large quantity of data could be amassed and subjected to statistical analysis within a short period of time.

\subsection{Piloting of Research Instruments}

The questionnaires were constructed and pre-tested in the field in order to determine their validity and reliability to a selected sample of 10 members of a group and one loan officer that were not to be among those who were surveyed in the main study.

\subsubsection{Reliability}

To ensure reliability the test-retest method was used where the questionnaire was administered to a few subjects and the answered questions were scored manually. The same questionnaires were administered to the same group after one week and again the score was recorded manually and compared to determine similarity. Pearson Product moment formula for test-retest was used to compute correlation coefficient in order to establish consistency in eliciting the same responses every time it was administered.

\subsubsection{Validity}

Validity involves establishing whether the questionnaire's content measures what is supposed to measure accurately. Questionnaires should measure the concepts under study accurately. The researcher's supervisor assessed the relevance of the content used in the questionnaire and recommendations incorporated in the final questionnaire.

\subsection{Data Collection Procedure}

Data was collected from both secondary and primary sources through the library, internet and questionnaires respectively.

\subsection{Data Analysis}

Data analysis was done using the descriptive and inferential statistics. Descriptive statistics was used to tabulate data and present it in tables, graphs and in description. Inferential statistics was used since a sample was under study yet conclusion was made about a larger population from which the samples were drawn. Data collected by use of questionnaires was analysed using statistical package for social scientists (SPSS) version 20 for windows and use of inferential statistics using correlation analysis. Descriptive statistic using percentages, 
modes and means were used to analyse quantitative data. Data was presented using tables, Bar graphs and pie charts.

\section{Data Analysis, Presentation and Findings.}

The study assessed the causes of default in repayment of loans advanced by WEDF (micro-credit) to small scale women entrepreneurs. Data analysis and findings was done using descriptive statistics in the form of tables, frequencies, percentages bar graphs and pie-charts and the analysis of the relationships between independent and dependent variables, a correlational inferential statistics were used. The findings of the were;

\subsection{Demographic characteristics of the borrowers.}

The findings on ages of WEDF loan borrowers were as shown in the table and bar graph below.

Table 2 Borrowers showing ages.

\begin{tabular}{|l|l|l|}
\hline Age & Frequency & Percentage \\
\hline Below 20 years & 0 & 0.0 \\
\hline $21-30$ year & 11 & 14.5 \\
\hline $31-40$ years & 29 & 38.2 \\
\hline 41-50 years & 31 & 40.8 \\
\hline Above 50 years & 5 & 6.5 \\
\hline Total & $\mathbf{7 6}$ & $\mathbf{1 0 0}$ \\
\hline
\end{tabular}

The findings revealed that $11(14.5 \%)$ borrowers were aged either between 21 and 30 years, $29(38.2 \%)$ were aged between 31 and 40 with the majority, $31(40.8 \%)$ being 41 and 50 years old and the remaining 5 (6.5\%) being over 50 years old this is also illustrated by the Bar graph Fig 2 below.

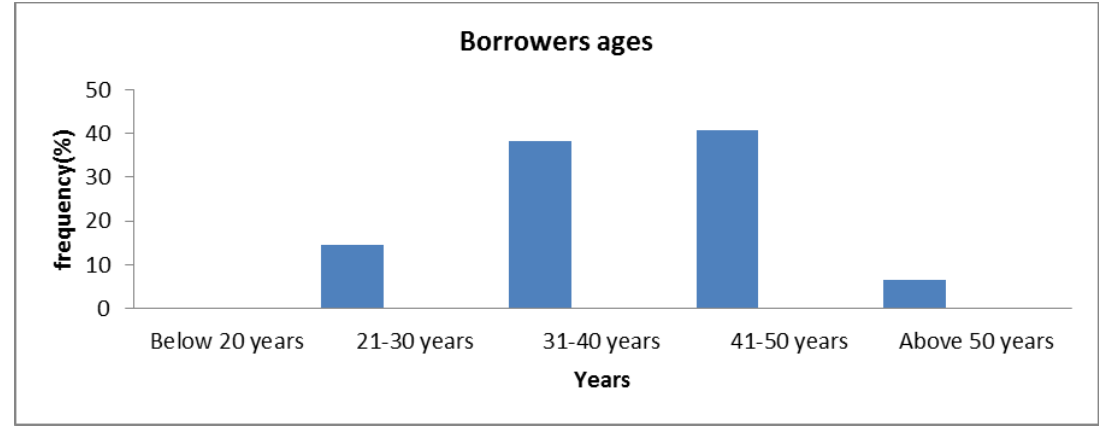

Figure 2.Bar graph showing borrowers ages.

Table 3 marital status of borrowers.

\begin{tabular}{|l|l|l|}
\hline Marital status & Frequency & Percentage \\
\hline Married & 46 & 60.5 \\
\hline Single & 15 & 19.7 \\
\hline Divorced & 9 & 11.8 \\
\hline Widowed & 6 & 7.9 \\
\hline Total & $\mathbf{7 6}$ & $\mathbf{1 0 0}$ \\
\hline
\end{tabular}

The findings on borrowers marital status showed that $46(60.5 \%)$ were married, $15(19.7 \%)$ were single, 9 (11.8\%) divorced while the remaining 6 (7.9\%) were widowed as summarized by the Pie chart Fig 3 below.

\section{Borrowers marital status}

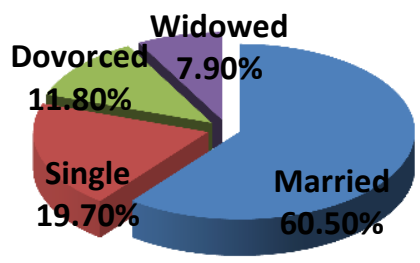

Figure 3.Pie chart showing borrowers marital status. 
Table 4 Borrowers numbers of children / dependents

\begin{tabular}{|l|l|l|}
\hline Number of children / dependents & Frequency & Percentage \\
\hline None & 1 & 1.3 \\
\hline $1-2$ & 18 & 23.7 \\
\hline $3-5$ & 42 & 55.3 \\
\hline $6-7$ & 12 & 15.8 \\
\hline More than 7 & 3 & 3.4 \\
\hline Total & $\mathbf{7 6}$ & $\mathbf{1 0 0}$ \\
\hline
\end{tabular}

The findings revealed that 1 (1.3\%) of the borrowers had no dependant, 18 (23.7\%) had either 1 or 2 children, with a majority, $42(55.3 \%)$ having between 3 to 5 children while $12(15.8 \%)$ had 6 or 7 dependants and the remaining $3(3.9 \%)$ over 7 children as shown by bar graph Fig 4 below.

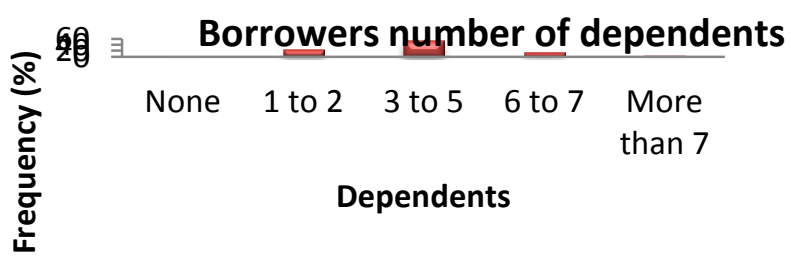

Figure 4. Bar graph showing borrowers number of dependents.

Table 5 Borrowers Level of education

\begin{tabular}{|l|l|l|}
\hline Level of education & Frequency & Percentage \\
\hline None & 12 & 15.8 \\
\hline Primary & 24 & 31.6 \\
\hline Secondary & 36 & 47.4 \\
\hline Diploma & 3 & 3.9 \\
\hline Degree & 1 & 1.3 \\
\hline Total & $\mathbf{7 6}$ & $\mathbf{1 0 0}$ \\
\hline
\end{tabular}

Findings on educational level showed that, $12(15.8 \%)$ of borrowers had no formal education, 24 (31.6\%) had primary education, $36(47.4 \%)$ had secondary education while $3(3.9 \%)$ had post-secondary diploma qualification and the remaining $1(1.3 \%)$ respondent being a degree holder as shown by the pie chart Fig 5 below.

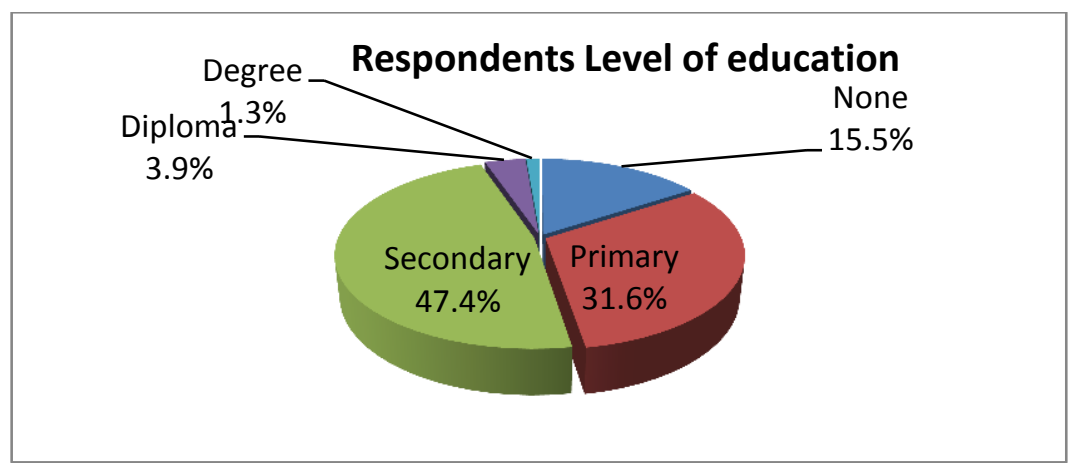

Figure 5. Pie chart representing borrowers level of education.

Table 6 showing borrower's occupation

\begin{tabular}{|l|l|l|}
\hline Occupation & Frequency & Percentage \\
\hline Business & 59 & 77.6 \\
\hline Farming & 9 & 11.8 \\
\hline Teaching & 5 & 6.6 \\
\hline Medical & 2 & 2.6 \\
\hline Others & 1 & 1.3 \\
\hline Total & $\mathbf{7 6}$ & $\mathbf{1 0 0}$ \\
\hline
\end{tabular}


Findings on occupation, showed that majority of the borrowers, $59(77.6 \%)$ were in business, 9 (11.8\%) practiced farming, $5(6.6 \%)$ in teaching, $2(2.6 \%)$ in the medical profession and the remaining $1(1.3 \%)$ being in other forms of occupation as shown by the pie-chart Fig 6 below.

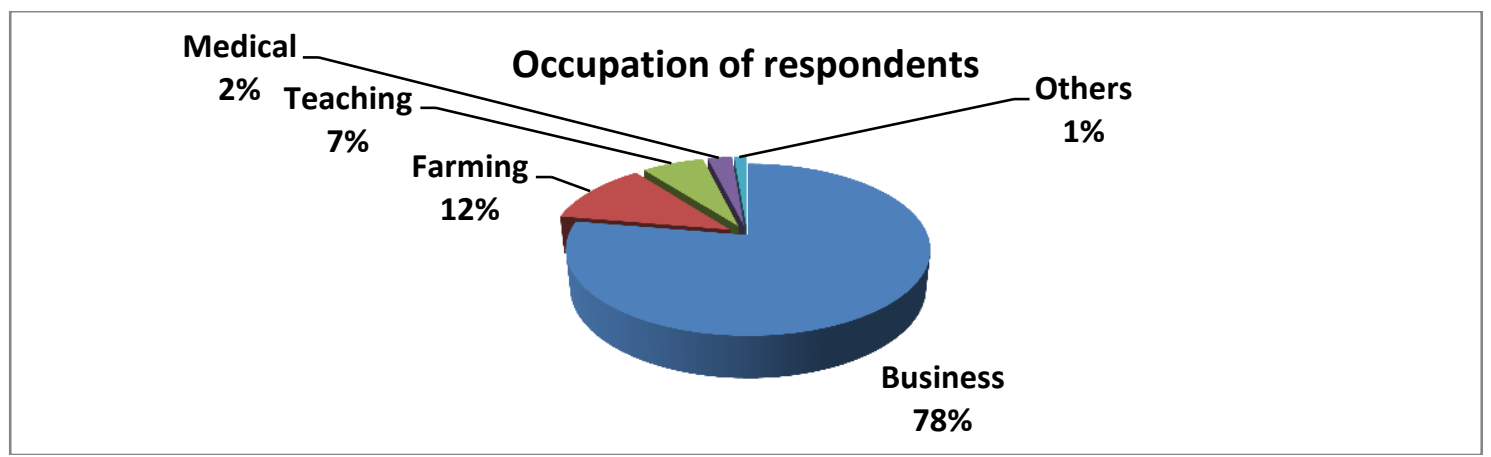

Figure 6. A pie-chart representing respondent's occupation.

\subsection{Loan acquisition}

Table 7 showing how many times the borrowers had taken a loan.

\begin{tabular}{|l|l|l|}
\hline How many times have you taken a loan? & Frequency & Percentage \\
\hline Once & 9 & 11.8 \\
\hline Twice & 12 & 15.8 \\
\hline Thrice & 31 & 40.8 \\
\hline Four times & 19 & 25.0 \\
\hline Five times & 5 & 6.6 \\
\hline Total & $\mathbf{7 6}$ & $\mathbf{1 0 0}$ \\
\hline
\end{tabular}

The findings revealed that out of the 76 women $9(11.8 \%)$ had borrowed once, $12(15.8 \%)$ twice, $31(40.8 \%)$ thrice, 19(25\%) four times and 5(6.6\%) borrowed five times as shown by the bar graph Fig 7 below.

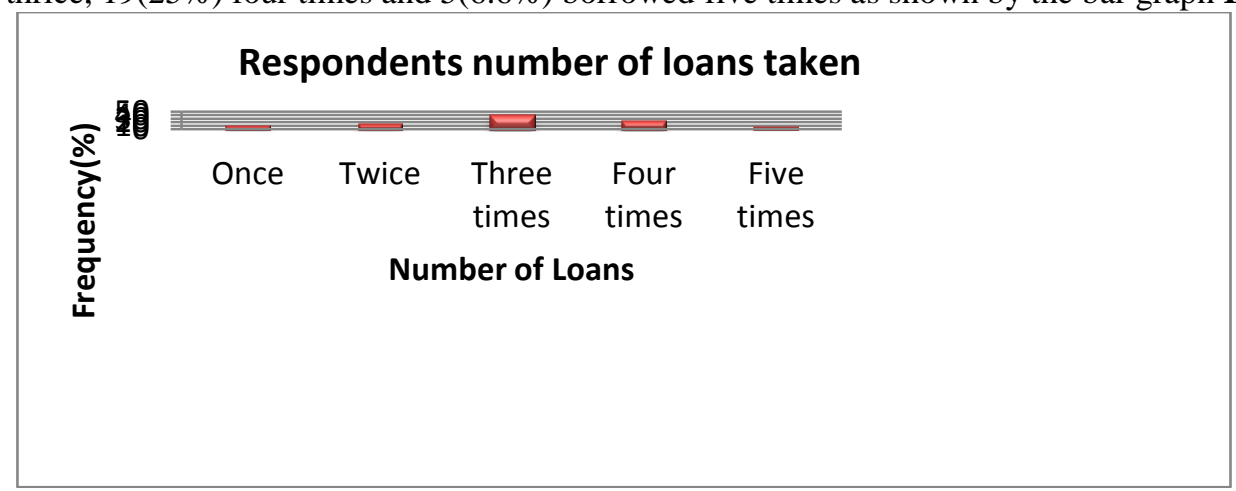

Figure 7. A bar graph showing borrower's number of loans taken.

Table 8 showing utilization of loan funds by borrower

\begin{tabular}{|l|l|l|}
\hline What did you do with the loan? & Frequency & Percentage \\
\hline Started Business & 69 & 90.8 \\
\hline Bought Food & 1 & 1.3 \\
\hline Paid school fees & 5 & 6.6 \\
\hline Paid medical bills & 1 & 1.3 \\
\hline Total & 76 & 100 \\
\hline
\end{tabular}

On utilization of borrowed funds majority of the borrowers, $69(90.8 \%)$ invested the whole loan in business, $1(1.3 \%)$ used part of it to meet immediate family needs such buying food, 5(6.6\%) used it to pay school fees and 1(1.3\%) paid medical bill this as shown by the pie-chart Fig 8 below. 


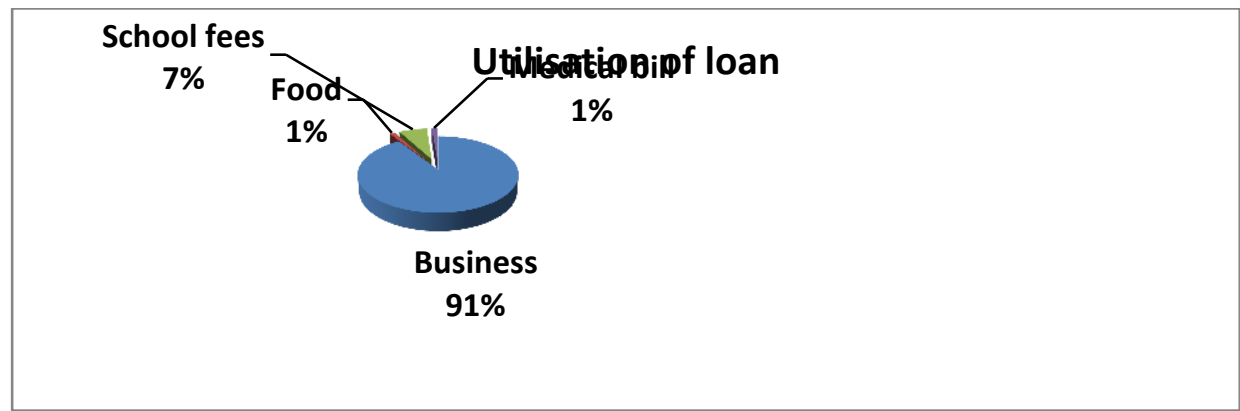

Figure 8. A pie chart representing utilization of loan.

Table 9 showing the amount of loan borrowed

\begin{tabular}{|l|l|l|}
\hline How much have you borrowed? & Frequency & Percentage \\
\hline $5000-10000$ & 6 & 7.9 \\
\hline $10001-15000$ & 5 & 6.6 \\
\hline $15001-20000$ & 6 & 7.9 \\
\hline $20001-25000$ & 18 & 22.4 \\
\hline Above 25000 & 41 & 55.2 \\
\hline Total & $\mathbf{7 6}$ & $\mathbf{1 0 0}$ \\
\hline
\end{tabular}

On the amount each had borrowed, 6(7.9\%) had borrowed between ksh5000 and ksh10000, 5(6.6\%) between ksh10001 and ksh15000, 6(7.9\%) between ksh15001 and ksh20000, 18(22.4\%) between ksh20001 and ksh25000, with the majority $41(55.2 \%)$ to have borrowed more than ksh25000 as shown in the bar graph Fig 9 below.

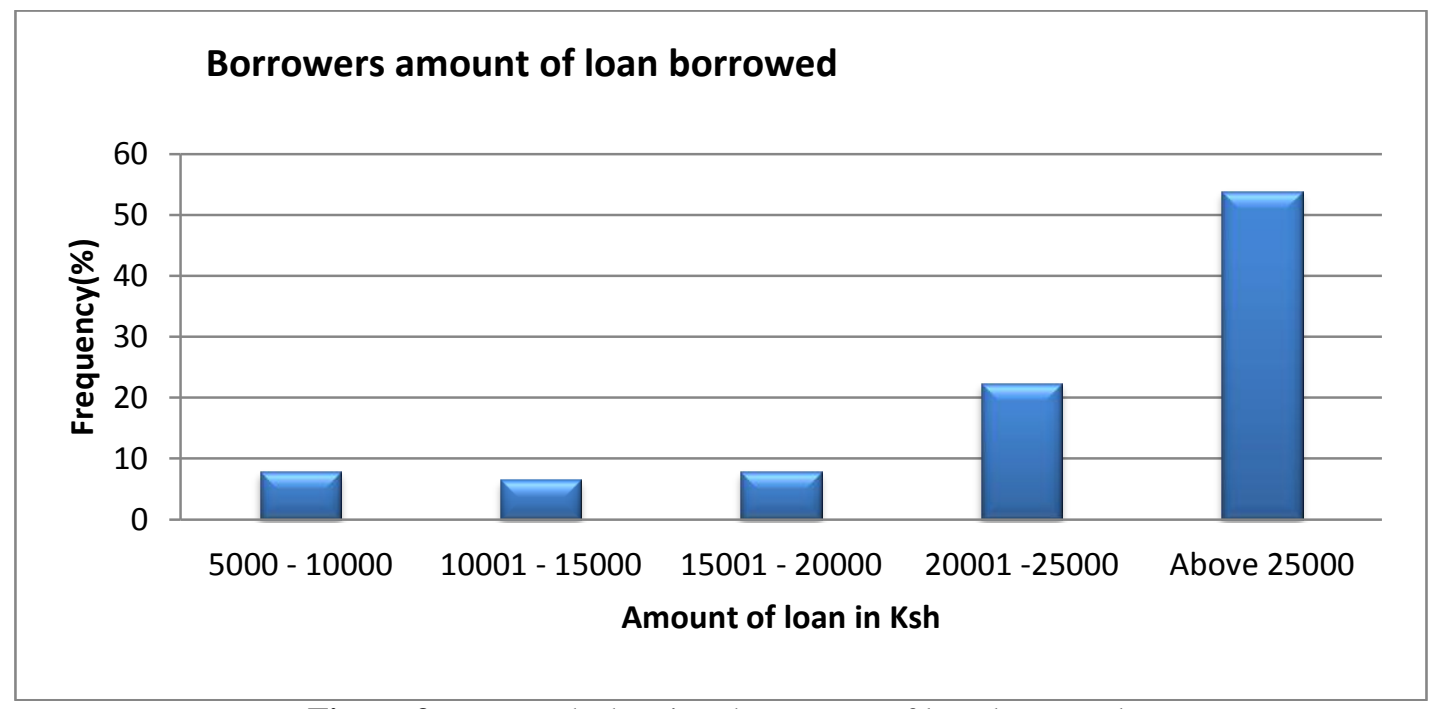

Figure 9. Bar graph showing the amount of loan borrowed.

Table 10 showing loan repayment schedule

\begin{tabular}{|l|l|l|}
\hline How was the repayment of the loan? & Frequency & Percentage \\
\hline Daily & $\mathbf{1 0}$ & $\mathbf{1 3 . 6}$ \\
\hline Weekly & 12 & 15.8 \\
\hline Two weeks & 12 & 15.8 \\
\hline Monthly & 42 & 54.8 \\
\hline Total & $\mathbf{7 6}$ & $\mathbf{1 0 0 . 0 0}$ \\
\hline
\end{tabular}

On loan repayment, out of the 76 respondents $10(13.16 \%)$ of them paid on daily basis, $12(15.79 \%)$ paid on weekly basis $12(15.79 \%)$ paid after every two weeks and $42(68.4 \%)$ paid on monthly basis as shown by the pie chart Fig 10 below. 


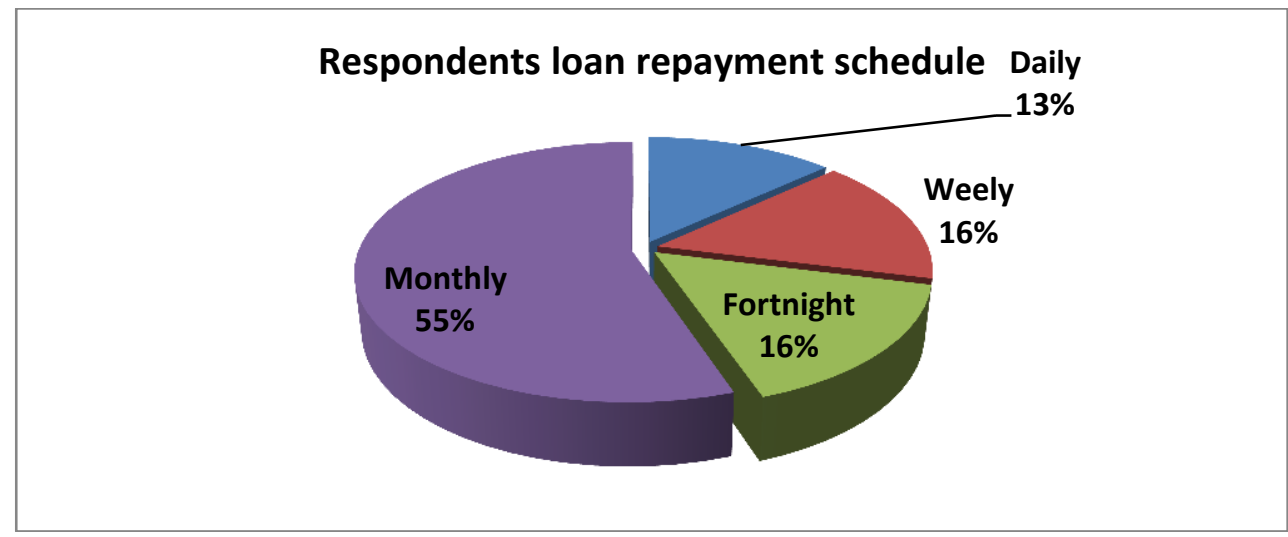

Figure 10. Pie chart showing the loan repayment schedule.

Table 11 showing cause of default in loan repayment.

\begin{tabular}{|l|l|l|}
\hline Cause of repayment problem & Frequency & Percentage \\
\hline Business collapsed & 32 & 42.1 \\
\hline Money taken by relative & 2 & 2.6 \\
\hline Used money to buy food & 23 & 30.3 \\
\hline Money/business was stolen & 4 & 5.3 \\
\hline Don't know & 7 & 9.2 \\
\hline No response & 8 & 10.5 \\
\hline Total & $\mathbf{7 6}$ & $\mathbf{1 0 0 . 0 0}$ \\
\hline
\end{tabular}

The findings showed that $32(42.1 \%)$ of the respondents their businesses collapsed thereby robbing them of a source of revenue for the loan repayment, 23 (30.3\%) having used the money to buy food, $2(2.6 \%)$ had given the loan money to their relatives while $4(5.3 \%)$ their businesses or money had been stolen thus causing repayment problem as shown by the pie chart Fig 11 below.

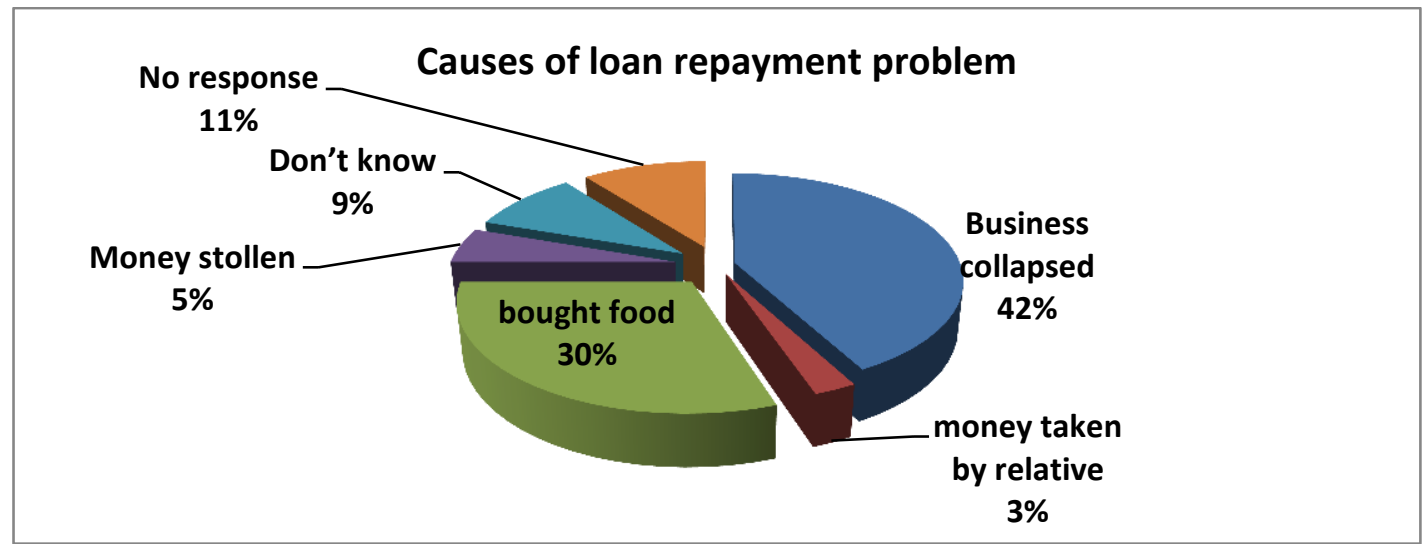

Figure 11.A pie chart showing causes loan repayment problem

\subsection{Influence of borrower's entrepreneurial skills on loan repayment.}

Table 12 showing the training attended by borrowers.

\begin{tabular}{|l|l|l|}
\hline Course attended by borrowers. & Frequency & Percentage \\
\hline Entrepreneurship & 33 & 43.4 \\
\hline Finance management & 10 & 13.2 \\
\hline Customer service & 5 & 6.6 \\
\hline All the above & 8 & 10.5 \\
\hline Others & 8 & 10.5 \\
\hline Non & 12 & 15.8 \\
\hline Total & $\mathbf{7 6}$ & $\mathbf{1 0 0 . 0 0}$ \\
\hline
\end{tabular}

The business training attended was said to be entrepreneurship for 33 (43.4\%) respondents, financial management for $10(13.2 \%)$ and customer service for $5(6.6 \%)$ respondents while $8(10.5 \%)$ others respondents had either attended all the three listed types of training or other types of training as shown by the pie-chart Fig 12 below. 


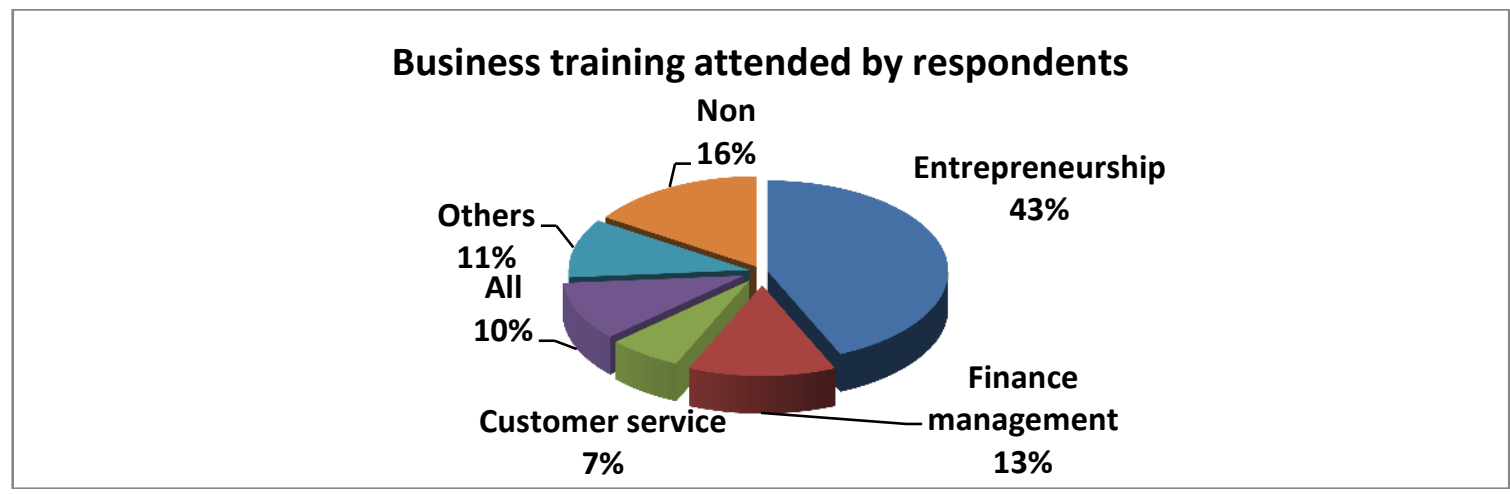

Figure 12. A pie chart showing the training attended by borrowers

Table 13 showing applicability of training to business

\begin{tabular}{|l|l|l|}
\hline Do you agree that the course was applicable to your business? & Frequency & Percentage \\
\hline SD & 29 & 38.2 \\
\hline D & 15 & 19.7 \\
\hline NS & 8 & 10.5 \\
\hline A & 17 & 22.4 \\
\hline SA & 7 & 9.2 \\
\hline Total & $\mathbf{7 6}$ & $\mathbf{1 0 0 . 0 0}$ \\
\hline
\end{tabular}

However, only a paltry $17(22.4 \%)$ considered the training as having assisted them to increase their income and only $24(31.6 \%)$ were of the opinion that the training they acquired had assisted them in managing the business which then enabled them to repay the loan as shown by the pie-chart Fig 13.below.

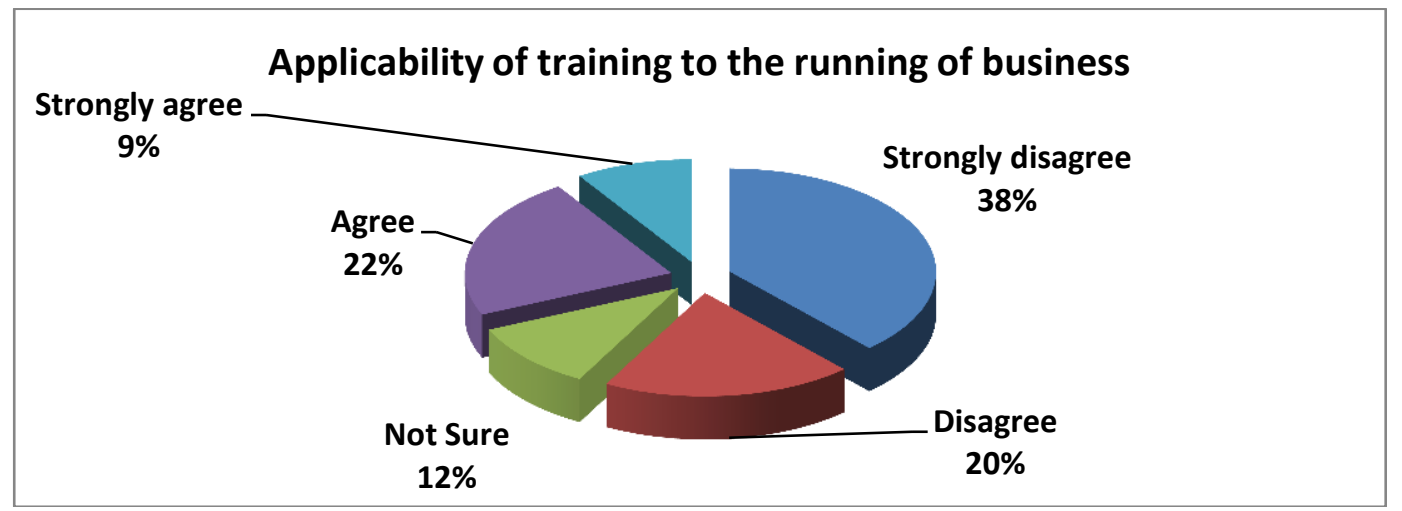

Figure 13. A pie-chart showing applicability of training on business.

4.4 How diversion of loan funds by borrowers influences loan repayment

Findings on diversion of loan funds by borrower's revealed that out of the 76 respondents $52(68.4 \%)$ had used the loan for other purpose not agreed upon while only $24(31.6 \%)$ had used the loan for the intended purpose as shown in the table 14 below.

Table 14 showing what the diverted loan was used for.

\begin{tabular}{|l|l|l|}
\hline What did you do with the money you diverted? & Frequency & Percentage \\
\hline Paid domestic expenses & 13 & 17.1 \\
\hline Paid medical Expenses & 16 & 21.1 \\
\hline Paid School fees & 25 & 32.9 \\
\hline All the above & 8 & 10.5 \\
\hline No response & 14 & 18.4 \\
\hline Total & $\mathbf{7 6}$ & $\mathbf{1 0 0 . 0 0}$ \\
\hline
\end{tabular}

The findings showed that $25(32.9 \%)$ of respondents used the loan granted towards school fees, 16 (21.1) settled medical bills and $13(17.1 \%)$ for domestic expenses as shown by the pie chart Fig 14 below; 


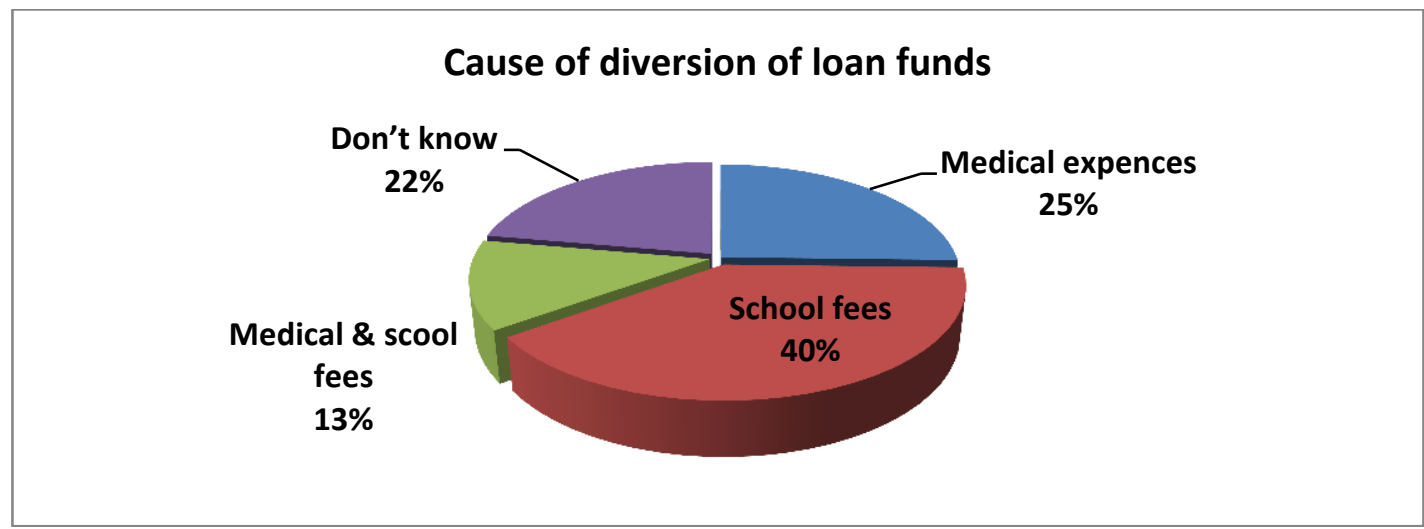

Figure 14. A pie chart showing causes of diversion of fund.

Table 15 showing how the diverted loan was paid

\begin{tabular}{|l|l|l|}
\hline How was the payment of the diverted loan? & Frequency & Percentage \\
\hline Never paid & 3 & 3.9 \\
\hline Very difficultly paid & 28 & 36.8 \\
\hline Difficultly paid & 18 & 23.7 \\
\hline Paid well & 17 & 22.4 \\
\hline Paid very well & 1 & 1.3 \\
\hline No response & 9 & 11.8 \\
\hline Total & $\mathbf{7 6}$ & $\mathbf{1 0 0 . 0 0}$ \\
\hline
\end{tabular}

Findings show that among those who had diverted the loans 3(3.9\%) never paid, the majority 28 $(36.8 \%)$ the repayment was very difficult, $18(23.7 \%)$ paid but with difficulties, 17 (22.4\%) paid well without any problem, with only $1(1.3 \%)$ respondent paid very well and $9(11.8 \%)$ had no response as shown by the pie chart Fig. 15 below.

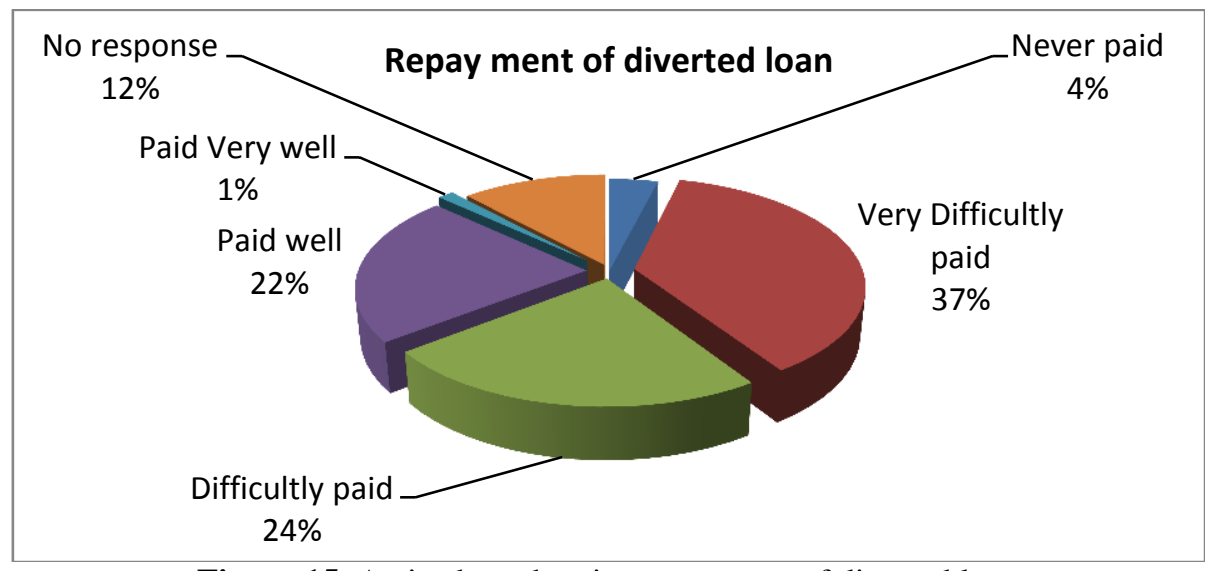

Figure 15. A pie chart showing repayment of diverted loan

\subsection{Relationship between elements of the conceptual framework.}

A correlational analysis test on the interrelationship between the elements of the conceptual framework and the dependent variable was determined and the results were as is shown in table 16 below. 
Table 16. Relationship between elements of the conceptual framework

\begin{tabular}{|c|c|c|c|c|c|c|}
\hline & & $\begin{array}{c}\text { Business } \\
\text { failure }\end{array}$ & $\begin{array}{l}\text { Gender } \\
\text { roles }\end{array}$ & Entrepreneurial skills & $\begin{array}{l}\text { Diversion of } \\
\text { funds }\end{array}$ & Parameter \\
\hline \multirow{4}{*}{ Business failure } & Pearson Correlation & 1 & $.449^{* *}$ & $-.548^{* 2 *}$ & -.215 & $.393^{* * 2}$ \\
\hline & Sig. (2-tailed) & & .000 & .000 & .083 & .002 \\
\hline & $\mathrm{N}$ & 76 & 76 & 76 & 76 & 76 \\
\hline & Pearson Correlation & $.449^{* *}$ & 1 & $-.257^{*}$ & $-.412^{* *}$ & $.488^{* *}$ \\
\hline \multirow[t]{3}{*}{ Gender roles } & Sig. (2-tailed) & .000 & & .034 & .001 & .000 \\
\hline & $\mathrm{N}$ & 76 & 76 & 76 & 76 & 76 \\
\hline & Pearson Correlation & $-.548^{* *}$ & $-.257^{*}$ & 1 & $.378^{* * 1}$ & $.395^{* *}$ \\
\hline \multirow[t]{3}{*}{ Entrepreneurial skills } & Sig. (2-tailed) & .000 & .034 & & .002 & .001 \\
\hline & $\mathrm{N}$ & 76 & 76 & 76 & 76 & 76 \\
\hline & Pearson Correlation & -.215 & $-.412^{* * 1}$ & $.378^{* * *}$ & 1 & $423^{* *}$ \\
\hline \multirow[t]{3}{*}{ Diversion of funds } & Sig. (2-tailed) & .083 & .001 & .002 & & .001 \\
\hline & $\mathrm{N}$ & 76 & 76 & 76 & 76 & 76 \\
\hline & Pearson Correlation & $.393^{* *}$ & $.488^{* *}$ & $.395^{* * 1}$ & $.423^{* * *}$ & 1 \\
\hline \multirow[t]{2}{*}{ Parameter } & Sig. (2-tailed) & .002 & .000 & .001 & .001 & \\
\hline & $\mathrm{N}$ & 76 & 76 & 76 & 76 & 76 \\
\hline
\end{tabular}

Table 4.7 contains information on the relationship between business failure, gender role, entrepreneurial skills and diversion of funds default of loan repayment. The results $(\mathrm{R}=0.488 ; \mathrm{P}=0.000 ; \mathrm{N}=76)$ show a significant positive correlation between the elements of gender roles and default of loan repayment at 0.05 level of significance, a positive and significant relationship between diversion of funds $(\mathrm{R}=0.423 ; \mathrm{P}=0.001$; $\mathrm{N}=76$ ) and default of loan repayment at 0.05 level of significance, a positive and significant correlation with entrepreneurial skills $(\mathrm{R}=0.395 ; \mathrm{P}=0.001 ; \mathrm{N}=76)$ and finally, a positive and significant correlation business failure $(\mathrm{R}=0.393 ; \mathrm{P}=0.002 ; \mathrm{N}=76)$ at 0.01 level of significance. This means that according to the respondents, gender roles was the factor most responsible for default of loan repayment followed by diversion of funds then lack of appropriate entrepreneurial skills and lastly business failure in decreasing order of effect.

\subsection{Summary}

\section{Summary, Conclusions and Recommendation}

The content of the analysis showed that to most of the respondents, the amount of loan given out by WEDF to them was not enough for their business needs, the accruing profit from the investment was low therefore they had problems with their loan repayment due to the low profit. With regard to the gender roles, a majority of the respondents felt that multiple and competing gender roles had an effect on their ability to repay loans as it robbed them of time to concentrate in the business thus contributing to default. Majority of the borrowers had attended training however many did not find the applicability of the training in running their businesses. Lastly, according to a majority of the borrowers, diversion of WEDF loan fund to other purposes other than its intended investment in income generating was found to be a reality due to the desperate conditions of most of the beneficiaries. Loan officers interviewed for the study observed that loan default was most predominant among married women an indicator that gender roles enhanced default particularly when the loanees had competing roles which robbed of time to concentrate in money generating activities or where the loaned chooses to divert the money to be used for other domestic purposes other than the intended one. They also acknowledged being aware of cases where business of borrowers had collapsed and suggested that business failure could most probably lead to default. 


\subsection{Conclusion}

Conclusions of the study findings were made based on the relationships that were established for each of the different research objectives. From the preceding discussion on causes of default in repayment of loans advanced by WEDF (micro-credit) to small scale women entrepreneurs in Msambweni constituency of Kwale County, the study established that business failure, competing gender roles, lack of appropriate entrepreneurial skills and diversion of funds were the major culprits with gender roles that compete with business management activities being the most predominant.

\subsection{Recommendation.}

From the observations made in the course of this study, it is deemed appropriate that various stakeholders should put in place the requirements for utilization of funds obtained in form of loans from WEDF to facilitate adequately loan repayment thus minimize default. To begin with, all stakeholders should work in concert to ensure that beneficiaries of WEDF are appropriately trained to equip them with requisite entrepreneurial skills thus minimize business failures cases which were found to often lead to loan repayment default. Then, the WEDF should consider increasing the amount given out to its members hence enhancing the viability of the projects initiated using such amounts. Further, beneficiaries of the WEDF should be encouraged to have other income generating activities besides the one due to the loan so as to minimize cases of diversion of loan moan to other unintended but critical needs.

\subsection{Suggestion for further research}

The following areas should be considered for further research:

i. A study of the effects of socio - cultural factors on the success of businesses due to loans from WEDF.

ii. A similar study to be replicated in other regions to compare their findings.

\section{References}

[1]. Arsyad, L. (2006). Assessing factors affecting the repayment rate of microfinance institutions: case study of village credit institutions of Gianyar, Bali. GadjahMada International Journal of Business, 8(2), 247-273.

[2]. Awoke, M.U. (2004).Factors affecting loan acquisitioned repayment patterns of smallholder farmers in Inlka North-East of Delta State Nigeria. Journal of Sustainable Tropical Agricultural Research, 9, 61-64.

[3]. Chirwa, E.W. (1997). An econometric analysis of the determinants of agricultural credit repayment in Malawi. African Review of Money and Banking. Supplement of the Saving and Development Journal, 1(2), 107-119.International Journal of Business and Social Science Vol. 1 No. 2; November 2010158

[4]. Conroy, J.D. (2002). Microfinance in Malaysia: Time to rebuild. The Foundation for Development Corporation. Brisbane. Australia.

[5]. Derban, W.K., Binner, J.M., \& Mullineux, A. (2005).Loan repayment performance in community development finance institutions in the UK. Small Business Economics, 25, 319-332.

[6]. Eze, C.C., \&Ibekwe, U.C. (2007).Determinants of loan repayment under the indigenous financial system in Southeast, Nigeria. The Social Sciences, 2(2), 116-120.

[7]. Godquin, M. (2004).Microfinance repayment performance in Bangladesh: how to improve the allocation of loans by MFIs. World Development, 32(11), 1909-1926.

[8]. Hoque, M.Z. (2000). Guided industrial credit. Monash University. http://www.bizresearchpapers.com/Document4.pdf. Retrieved on 22 April 2010

[9]. Inter- American Development Bank. (1997). Technical guide for the Analysis of Microenterprise Finance Institutions. Microenterprise Division. Washington.

[10]. Khandker, S.R., Khalily, B., \& Khan, K. (1995). Grameen Bank: Performance and sustainability..World Bank Discussion Paper, 306, The World Bank, Washington, DC.

[11]. Kurwijila, R., \& Due, J.M. (1991).Credit for women's income generation: A Tanzanian case study. Canadian Journal of African Studies, 25(1), 90-103.

[12]. Ledgerwood, J. (1999). Microfinance Handbook: An Institutional and Financial Perspective. The World Bank. Washington.

[13]. Llanto, G.M., Garcia.E.,\& Callanta, R. (1996). An assessment of the capacity and financial performance of microfinance institutions: the Philippine case. Discussion Paper 96-12, Philippine Institute for Development Studies, Makati, Philippines.

[14]. Maria, U. (2004). Essay on the Dynamics of Microfinance. Unpublished Master Dissertation, University of Maryland College Park United States. (C) Centre for Promoting Ideas, USA www.ijbssnet.com 159

[15]. Murdoch, J. (1999). The microfinance promise. Journal of Economic Literature, 37(4), 1569-1614.

[16]. Nannyonga, H. L. (2000). Determinants of repayment behaviour in the Centenary Rural Development Bank in Uganda. Unpublished Doctoral Dissertation. The Ohio State University. United States.

[17]. Nikhade, D.M., Shinde, P.S., \&Nighot, S.M. (1994).Crop loan repayment behaviour in cotton growers. Agricultural Banker, October/December, 13-16.

[18]. Njoku, J. E. (1997). Determinants of loan repayment under the special emergency loan scheme (SEALS) in Niger: A case study in Imo state. African Review of Money Finance and Banking, 1, 39-51.

[19]. Oke, J.T.O., Adeyemo, R., \&Agbonlahor, M.U. (2007).An Empirical Analysis of Microcredit Repayment in South western Nigeria. Humanity\& Social Sciences Journal, 2(1), 63-74.

[20]. Oladeebo, J.O., \& Oladeebo, O.E. (2008).Determinant of loan repayment among smallholder farmers in Ogbomoso Agricultural Zone of Oyo State, Nigeria. Journal of Social Science, 17(1), 59-62.

[21]. Orodho,J (2008) Techniques ofwriting Research Proposal and reports in education. A social sciences. Nairobi, Kennezja enterprises.

[22]. Ozdemir, O., \&Boran, L. (2004).An empirical investigation on consumer credit default risk. Discussion Paper.2004/20.Turkish Economic Association. 
[23]. Papias, M.M \&Ganesan, P. (2009). Repayment behaviour in credit and savings cooperative societies. Empirical and theoretical evidence from rural Rwanda_International Journal of Social Economics, 36(5), 608-625.

[24]. Petersen, M.A., \&Rajan, R.G. (1994).The benefits of lending relationships: Evidence from small business data. The Journal of Finance, 49(1), 3-38.

[25]. Rambabu, P.D., \&Eswaran, Y.P. (1994).Factors influencing attitude of the farmers towards farm credit. Agricultural Banker, October/December, 25

[26]. Reinke, J. (1998). How to lend like mad and make a profit: a micro-credit paradigm versus the start-up in South Africa. Journal of Development Studies.

[27]. Roodman, D. (2006). Microfinance as Business. Centre for Global Development, ABN-AMRO.

[28]. Roslan, A.H., Faudziah, Z.A., Mohd Saifoul, Z.N., \&Rahimah, M. (2007).Microfinance service for microenterprise: Good practices and performance of selected microfinance institutions in Malaysia. Journal of Yala Rajabhat University, 2(1), 31-45.

[29]. Roslan, A.H., \& Mohd Zaini, A. K. (2009).Determinants of microcredit repayment in Malaysia: the case of Agro bank. Humanity \& Social Sciences Journal,

[30]. Saleh, S.A., \&Ndubisi, O.N. (2006).An evaluation of SME development in Malaysia. International Review of Business Research Papers, 2(1), 1-14.

[31]. Schoombee, A. (2000). Getting South African bank to serve micro-entrepreneurs: An analysis of policy options. Development Southern Africa.17 (5). 751- 767

[32]. Silwal, A.R. (2003). Repayment performance of Nepali Village Banks. Unpublished Master Dissertation. Swarthmore College, Swarthmore.

[33]. Sharma, M., \& Zeller, M. (1997).Repayment performance in group based credit programmes in Bangladesh. World Development, 25(10), 1731-1742.

[34]. Sterns, K. (1995). The hidden beast: Delinquency in micro enterprise credit programme.ACCION Discussion Thesis Document No.6.

[35]. Tedeschi, G. A. (2008). Overcoming selection bias in microcredit impact assessments: a case study in Peru. Journal of Development Studies, 44(4), 504-518.

[36]. UNCDP. (2005). Core Performance Indicators for Microfinance. United Nations Capital Development Fund.

[37]. Ugbomeh, G.M.M., Achoja, F.O., Ideh, V., \&Ofuoku, A.U. (2008).Determinants of loan repayment performance among women self-help groups in Bayelsa State, Nigeria. Agriculture Conspectus Scientifics, 73(3), 189-195.

[38]. Vigenina, D., \&Kritikos, A.S. (2004).The individual micro-lending contract: is it a better design than joint liability? Evidence from Georgia. Economic Systems, 28, 155-176.

[39]. Zeller, M. (1998). Determinant of repayment performance in credit groups: The role of program design, intragroup risk pooling, and social cohesion. Economic Development and Cultural Change, 46(3), 599-621. 